\title{
Factors that influence teachers' dysphonia: a review
}

\author{
Amanda Kelly Silva de Albuquerque; Anayres Silva de Lima²; Maria de Fátima Silva de Sousa; \\ Emanuella Barros de Souza Oliveira Alvares ${ }^{4}$; Allyson Rodrigo de Oliveira Lopes ${ }^{5 *}$
}

1 Academic in the Biologics Sciences at UNIVISA, Centro Universitário da Vitória de Santo Antão, Pernambuco - Brazil.

2 Specialist Nurse in family health from the Federal University of Pernambuco and specialist in Pre-hospital Care from the Federal University of Recife, Pernambuco - Brazil

3 Speech therapist Master in Human Communication Health, Federal University of Pernambuco - UFPE. Recife, Pernambuco - Brazil.

4 Professor of the Degree Course in Biologics Sciences at UNIVISA, University Center of Vitória de Santo Antão, Pernambuco - Brazil.

5 Professor of the Degree Course in Biologics Sciences at UNIVISA, University Center of Vitória de Santo Antão, Pernambuco - Brazil.

E-mail adresses: amanda-kelly2011@hotmail.com (Amanda Kelly Silva de Albuquerque), anayreslima@hotmail.com (Anayres Silva de Lima), fatimasousa.scc@hotmail.com (Maria de Fátima Silva de Sousa), emanuella.barros@hotmail.com (Emanuella Barros de Souza Oliveira Alvares), allysonlopes85@gmail.com (Allyson Rodrigo de Oliveira Lopes)

*Corresponding author

\section{To cite this article:}

Albuquerque, A.K.S.; Lima, A.S.; Souza, M.F.S.; Alvares, E.B.S.O.; Lopes, A.R.O. Factors that influence teachers' dysphonia: a review. International Journal of Sciences. Vol. 1, No. 3, 2021, pp. 121-125. ISSN 2763-5392.

Received: 05 15, 2021; Accepted: 05 16, 2021; Published: 05 24, 2021

\begin{abstract}
Through the literature review, the results of this study indicate that the use resulting from the voice in the work environment can trigger serious vocal problems associated with several factors and especially when used in excess. Objective: To analyze the factors that influence the loss of teachers' voices, indicate the incidence, causality factors and possible influences. Methodology: articles and books were surveyed with search in the following databases: Lilacs, Google Scholar, PubMed, Scielo and in the book Dysphonia's: diagnosis and treatment. Result: Dysphonic disorder has been increasingly frequent in teachers, and may be caused by hereditary, behavioral, lifestyle and mainly by excessive use of the voice. Conclusion: The use resulting from the voice in the work environment has triggered serious problems in the voice and often led the teacher to absenteeism from the work environment.
\end{abstract}

Keywords: Teachers. Dysphonia. Vocal folds

\section{Introduction}

The sound of the human voice is an individual characteristic that reflects the identity of the subject, is a resource that allows reaching the other and relating to it, however changes in the voice can cause vocal discomfort, causing a negative impact on the listener, influencing interpersonal relationships, harming social life, interfering at work and affecting the well-being of the individual ${ }^{21}$.

Dysphonic disorder is represented by any alteration that prevents the voice from fulfilling its basic role ${ }^{11}$, it is usually the first and most obvious feeling of laryngeal disease ${ }^{12}$. Clinically, the disorder causes vocal alterations preventing the natural production of the voice, which may cause a compromise in the communication of teachers.

According to Aronson (1980) dysphonic disorder is related, in addition to communication, with the social, personal and economic of the individual. It can be caused by the interaction between hereditary and behavioral factors, lifestyle and occupational factors, but it is believed that the main factor is the excessive use of voice ${ }^{4}$.

The excessive use of voice in the work environment triggers a process of vocal alteration in teachers that worsens over time, bringing several consequences to the lives of teachers ${ }^{15}$.

Some studies on the quality of life of these workers, related to the teachers' vocal health, have shown that teachers have more dysphonic complaints than other professionals and that most of them have a pleasant voice, but also have difficulties in the perception of the disease process ${ }^{3}$. For these workers to maintain a healthy voice in an unstable work environment, it is one of the greatest difficulties faced, due to a very large workload and an audience that is composed most often by students who do not always want to receive their teachings ${ }^{7}$.

Studies based on the application of questionnaires show 
the difference in the vocal symptoms of teachers of different school levels and both ${ }^{24}$. The incidence of disorders among teachers varies according to the population studied and the methodology used for its finding. The nascent symptoms of voice disorder have an insidious onset, and worsen during the week and the school semester, due to excessive use of the voice, and tend to have an improvement during rest or vacation, but these symptoms tend to worsen without expectation ofimprovement ${ }^{13}$. The most common symptoms of the disorder are: hoarseness, vocal fatigue, ardor and/or pain in the throat and neck region, difficulty in maintaining the voice, variations in fundamental frequency, lack of volume and vocal projection, loss in vocal efficiency, little resistance to speech and speech or total loss of voice ${ }^{13}$.

There are several proposals for the classification of dysphonia, the most used, has as basic factors, being: Functional, functional and organic dysphonia. Functional dysphonia is common in teachers, since they do not receive adequate guidance to care for the voice and are exposed to inadequate working conditions. This type of dysphonia is based on vocal behavior, which is a process of vocal emission that results from the inappropriate use of voice ${ }^{24,5}$. Organfunctional dysphonia is due to a late diagnosed functional dysphonia that progresses to a secondary organic lesion. And organic dysphonia is associated with other diseases or due to important anatomical changes in the phonatory apparatus, endocrine alterations such as hyperthyroidism, alteration of sex hormones and gastroesophageal reflux are some of the most frequent causes of organic dysphonia amongprofesores ${ }^{9}$.

For the most, there are legal bases on the recognition of this disorder as DVRT or Work-Related Voice Disorder, however, vocal alterations have not yet been recognized as a harm to workers' health ${ }^{3}$.

Moreover, it is in the midst of all this discussion that questions arise about the symptoms for triggering this disorder and for its proper treatment, the scarcity of preventive actions for this class of workers reflects in the lack of public policies aimed at the teacher, who should be encouraged to be self-careful with the voice, since the vocal disorder brings consequences to the individual if not treated correctly ${ }^{16,22}$.

Therefore, this article aims to conduct a review of the literature on the loss of voice by teaching practices. Therefore, the information contained herein is discussed and provided regarding the main vocal alterations found in teachers, risk factors, vocal production and prevention conducts for vocal disorders.

\section{Methodology}

The present work is a bibliographic review, where articles and books were surveyed with search in the following databases: Lilacs, Google Scholar, PubMed, SciELO and in the book Dysphonia's: diagnosis and treatment.

Sources were analyzed between 2007 and 2019, and the following descriptors were applied in the search for articles: "Professors", "Dysphonia" and "Vocal folds".

18 articles were selected and included according to the eligibility criteria. The inclusion criteria were: articles in
English, Spanish and Portuguese, in the last seven years, in order to observe, describe and analyze the impact and commitment that dysphonic dysbiosis offer the life of the teacher. Exclusion criteria were literature review or metaanalysis articles.

\section{Results and Discussions}

Studies were conducted with the purpose of investigating the cause of voice loss in teachers, and 18 articles were selected where a literature review was performed so that it could verify the main factor that causes dysphonia in teachers.

Table 1. Analysis of the results of each document.

\begin{tabular}{|c|c|}
\hline es & Contents \\
\hline Gamma et al. & $\begin{array}{l}\text { Study with dysphonic and non-dysphonic } \\
\text { elementary school teachers, where the same } \\
\text { vocal intensity was observed in both groups, } \\
\text { but with the continuous use of voice } \\
\text { dysphonic teachers obtained the intensity of } \\
\text { their highest voice. }\end{array}$ \\
\hline Abou-Rafée & $\begin{array}{l}\text { It verified the self-perception of vocal fatigue } \\
\text { of dysphonic teachers in school activity who } \\
\text { sought speech therapy. }\end{array}$ \\
\hline $\begin{array}{l}\text { Buosi, Ferreira, } \\
\text { Momenson } \\
\text { Santos }\end{array}$ & $\begin{array}{l}\text { Evaluative analysis using auditory perception } \\
\text { as an essential item to have good vocal } \\
\text { feedback, if the individual does not listen well } \\
\text { consequently, he will have difficulty } \\
\text { monitoring his voice for the proper use of it. }\end{array}$ \\
\hline $\begin{array}{c}\text { Garden, Barreto, } \\
\text { Asunción }\end{array}$ & $\begin{array}{l}\text { The present study showed that both the } \\
\text { variables of work organization and vocal and } \\
\text { mental health are associated with a worse } \\
\text { quality of life related to the voice. }\end{array}$ \\
\hline Aragon et al. & $\begin{array}{l}\text { It demonstrated that the social and } \\
\text { professional use of the voice, resulting from } \\
\text { the school activity, in the period of two hours } \\
\text { and } 30 \text { minutes did not cause alterations in } \\
\text { vocal quality, analyzed in a perceptual- } \\
\text { auditory way. }\end{array}$ \\
\hline Amaral et al. & $\begin{array}{l}\text { It demonstrated that teachers with vocal risk } \\
\text { have worse self-assessment of voice and } \\
\text { greater discomfort of the vocal tract, which } \\
\text { increases after four and eight hours of the } \\
\text { same working day, which may indicate the } \\
\text { development of dysphonia }\end{array}$ \\
\hline Luchesi et al. & It demonstrated the \\
\hline
\end{tabular}




\begin{tabular}{l|l}
\hline & $\begin{array}{l}\text { multidisciplinary interventions in the } \\
\text { promotion and prevention of the teacher's } \\
\text { vocal health, although this fact is not } \\
\text { evidenced in the perception of some teachers }\end{array}$ \\
\hline Santos et al. & $\begin{array}{l}\text { When they experience difficulties in vocal } \\
\text { production, teachers seek treatment with } \\
\text { speech therapists so that losses in their } \\
\text { professional career are avoided. }\end{array}$ \\
\hline \multirow{5}{*}{ Amorim et al. } & $\begin{array}{l}\text { It evaluated the publications on the vocal } \\
\text { alterations resulting from the work, } \\
\text { evidencing that there are few articles in the } \\
\text { library investigated focusing on the aspect of } \\
\text { the teacher's vocal health at work, considering } \\
\text { that the voice is fundamental in oral } \\
\text { communication and interpersonal } \\
\text { relationships } \\
\text { Resear }\end{array}$ \\
\hline
\end{tabular}

Research done with teachers showed that they

only noticed differences in voices after

Medeiros et al. $\quad$ consultation with speech therapists. And that the delays in perceiving such changes bring difficulty in the teaching process of teachers

This case-control study confirmed the

Giannini, $\quad$ association between voice disorder in teachers

Latorre, Ferreira of the municipal school system and stress in teaching work

It demonstrated the need for greater reflection

Ferracciuas and attention of the legislation in force on the

Almeida main issues and deficiencies arising from voice disorders related to the teacher's work

\begin{tabular}{c|l}
\hline Park, Behlau & $\begin{array}{l}\text { Verified the impact on the life of the teacher } \\
\text { of a possible loss of voice }\end{array}$ \\
\hline Ferreira et al & $\begin{array}{l}\text { It observed the number of laws in favor of the } \\
\text { vocal health of teachers. }\end{array}$ \\
\hline Alves, Araújo, & $\begin{array}{l}\text { Demonstrated the adoption of preventive and } \\
\text { educational strategies in the integral care of } \\
\text { these professionals for the proper use of voice }\end{array}$ \\
\hline Ortiz et al. & $\begin{array}{l}\text { It demonstrated that the work environment } \\
\text { influences the worsening of voice quality, the } \\
\text { main symptoms were dysphonia and vocal } \\
\text { fatigue. }\end{array}$ \\
Alves et al. & $\begin{array}{l}\text { He says that teachers acquire dysphonia in the } \\
\text { workplace because they do not know the } \\
\text { basics of how to care for their voice, and that }\end{array}$ \\
\hline
\end{tabular}

\begin{tabular}{l|l}
\hline & $\begin{array}{l}\text { many tend to move away from work because } \\
\text { of the worsening of the disease. }\end{array}$ \\
\hline Cortez et al. & $\begin{array}{l}\text { Collect data in the literature that were related } \\
\text { to the teaching work, also showing the } \\
\text { importance of speech therapy in the } \\
\text { development of strategies for the prevention } \\
\text { of dysphonia. }\end{array}$ \\
\hline Source: Article data
\end{tabular}

Through the review of the selected articles, it can be observed that several factors can cause the loss of the voice, being them: hereditary, behavioral factors, lifestyle, but for teachers the main factor is the excessive use of voice ${ }^{4}$.

According to ${ }^{21}$, teaching is one of the activities with the highest vocal risk, and the teacher has not yet understood the importance of voice in the work environment and how much care for it is necessary within the scope of his profession.

The class of teachers is the one that demonstrates the most incidence for dysphonia, compared to professionals who use voice as the main work instrument. In some articles it was observed that the work environment influences the worsening of voice quality and that the class of teachers is the one who complains most about vocal fatigue because of spending hours teaching, often in inappropriate places, with bad acoustics and with little rest ${ }^{1,2,8,20}$.

When self-assessment was applied with dysphonic and non-dysphonic teachers, it was demonstrated that dysphonic teachers had worse vocal self-assessment and that teachers have twice as much complaint as vocals as non-teachers ${ }^{1}$.

It could also be observed about the auditory-perceptual process and that teachers are in the category of high risk for the development of vocal disorders, showing that auditory perception plays an important role in vocal feedback, when listening well consequently if they have a good voice. When you don't have a good vocal perception, you don't notice the intensity of the voice ${ }^{8,6}$. It is necessary to recognize early symptoms in order to take care of the voice correctly, since teachers have difficulty in perceiving the disease thus contributing to the worsening of the voice ${ }^{18,19}$.

Detecting it at first would avoid problems such as absenteeism from work due to its worsening. At the end of the school day, teachers present a hoarse, tired and fatigued voice, because they use their voice in excess within the work environment, often inadequate to work ${ }^{10}$.

Although there are laws for the protection of dysphonic or non-dysphonic teachers, they are still very superficial about promoting workers' health ${ }^{23}$. The lack of public policies to encourage teachers to have self-care with their voice demonstrates the negligence with the worker's health, since dysphonia can have serious consequences when not properly cared for, because if there is a disease problem it can lead to the removal of teachers from their work environment ${ }^{17}$.

Even though it is recognized as a DVRT, the changes are not considered to be an aggravation of the health of the worker ${ }^{14}$. Voice care should be encouraged in this class of workers, thus preventing future injuries. 
The treatment of dysphonia is carried out with the help of speech therapists because this health professional performs from the awareness, evaluation and treatment of these alterations together with a multidisciplinary team and diagnosis, with the purpose of returning quality of life and contributes to the formation and relationship between teacher and student through communication.

Analyzing some articles, it was observed that there are few who talk about the vocal alterations resulting from the work and that they are harmful to the health of the teacher. Also showing that it is necessary the help of a speech therapist to minimize the situation, through specific examinations ${ }^{3}$.

Speech therapy has advanced in research in relation to the vocal health of workers and laws that ensure the care of the voice $^{21}$, the speech therapist is the professional responsible for caring for and empowering for the proper use of the voice, besides articulating with the legislative power and teachers for the creation of vocal health programs of the worker ${ }^{13}$ (returns quality of life and contributes to the formation and relationship between teacher and student through communication).

\section{Conclusions}

The results of the present study show that the excessive use of voice in the work environment triggers several problems to the teachers' voice, associated with several factors, and it is necessary to encourage them to take care of their voice with the help of the responsible professional, the speech therapist, because the worsening of this disorder can cause serious problems to the health of the teacher, leading him to the absenteeism of his work environment.

It is suggested that projects be developed to train teachers about voice care, and that they be encouraged to have greater self-care with their main work instrument and that they be accompanied during their school career by a speech therapist, avoiding future problems during their work day.

\section{References}

[1] ABOU-RAFÉE, M. et al. Fadiga vocal em professores disfônicos que procuram atendimento fonoaudiológico. In: CoDAS. Sociedade Brasileira de Fonoaudiologia, São PauloSP. 2019.

[2] ALMEIDA, A. A. F. de et al. Características vocais e de personalidade de pacientes com imobilidade de prega vocal. In: CoDAS. Sociedade Brasileira de Fonoaudiologia, p. 178- 185. João Pessoa- PB. 2015.

[3] ALVES, L. A. et al. Alterações da saúde e a voz do professor, uma questão de saúde do trabalhador. Revista Latino-americana de Enfermagem, Ribeirão Preto - SP. v. 17, n. 4. 2009.

[4] ALVES, L. P.; ARAÚJO, L. T. R.; NETO, J. A. X. Prevalência de queixas vocais e estudo de fatores associados em uma amostra de professores de ensino fundamental em Maceió, Alagoas, Brasil. Revista Brasileira de Saúde Ocupacional, São Paulo - SP. v. 35, n. 121, p. 168-175. 2010.

[5] AMARAL, A. C. et al. Desconforto do trato vocal em professores após atividade letiva. In: CoDAS. p. e20160045e20160045. São Paulo-SP. 2017.

[6] ARAGÃO, A. N. et al. Análise da qualidade vocal antes e após o uso profissional e social da voz. AudiolCommun Res, 19(3), 209-14. Belo Horizonte- MG, 2014.

[7] BRASIL, C. C. P. et al. Entrelaçamento voz e emoção na percepção docente sob a ótica da fenomenologia de MerleauPonty. Interface-Comunicação, Saúde, Educação, Botucatu SP. 2018

[8] BUOSI, M. M. B.; FERREIRA, L. P.; MOMENSOHNSANTOS, T. M. Percepção auditiva de professores disfônicos. Audiol.,Commun. res, 18(2), 101-108. Fernandópolis (SP). 2013.

[9] CAPOROSSI, C.; FERREIRA, L. P. Sintomas vocais e fatores relativos ao estilo de vida em professores. Revista CEFAC, v. 13, n. 1, p. 132-139, São Paulo- SP. 2011.

[10] CIELO, C. A.; DE MORAES LIMA, J. P.; CHRISTMANN, M. K. Comparação dos efeitos do fingerkazoo e da fonação em tubo em mulheres com voz normal. Audiol.,Commun. res, 21, e1554-e1554. Santa Maria (RS), 2016

[11] DE AMORIM, G. O. et al. Biofeedback in dysphonia-progress and challenges. Brazilian journal of otorhinolaryngology, Recife- PE, v. 84, n. 2, p. 240-248. 2018.

[12] FAWCUS, Margaret. Voz hiperfuncional: a síndrome do mau uso e abuso. In: Distúrbios da voz e seu manejo. Springer, Boston, MA, 1991.p. 139-175.

[13] FERREIRA, L. P. et al. Políticas públicas e voz do professor: caracterização das leis brasileiras. Revista da Sociedade Brasileira de Fonoaudiologia, São Paulo - SP. p. 1- 7. 2009.

[14] FERRACCIU, C. C. S.; DE ALMEIDA, M. S. O distúrbio de voz relacionado ao trabalho do professor e a legislação atual. Revista CEFAC, São Paulo - SP. v. 16, n. 2, p. 628- 633. 2014.

[15] GIANNINI, S. P. P.; LATORRE, M. D. R. D. D.; FERREIRA, L. P. Distúrbio de voz e estresse no trabalho docente: um estudo caso-controle. Cadernos de Saúde Pública, 28, 2115-2124. Rio de Janeiro-RJ., 2012.

[16] JARDIM, R.; BARRETO, S. M.; ASSUNÇÃO, A. A. Condições de trabalho, qualidade de vida e disfonia entre docentes. Cadernos de Saúde Pública, Rio de Janeiro - RJ. v. 23, p. 2439-2461, 2007.

[17] LUCHESI, K. F. et al. Problemas vocais no trabalho: prevenção na prática docente sob a óptica do professor. Saúde e Sociedade, 18, 673-681. S]ao Paulo-SP. 2009.

[18] MEDEIROS, A. M. et al. Distúrbios da voz: representações sociais por professores em tratamento fonoaudiológico. Distúrbios da Comunicação, v. 28, n. 3, São Paulo-SP., 2016.

[19] MEDEIROS, J. D. S. A. et al. Sintomas vocais relatados por professoras com disfonia e fatores associados. AudiologyCommunication Research, 21. Belo Horizonte-MG, 2016.

[20] ORTIZ, E. et al. Multidisciplinary protocol proposal for professional dysphonia: preliminarystudy. Revista Brasileira de Otorrinolaringologia, v. 70, n. 5, p. 590-596, Campinas- SP. 2004

[21] PARK, K.; BEHLAU, M. Perda da voz em professores e não professores Voiceloss in teachersand non-teachers. 
RevSocBrasFonoaudiol, São Paulo- SP. v. 14, n. 3, p. 463-9, 2009.

[22] SANTOS, L. R. et al. Adesão das professoras disfônicas ao tratamento fonoterápico. In CoDAS (Vol. 25, No. 2, pp. 134139). Belo Horizonte-MG, 2012

[23] SERVILHA, E. A. M., Ferreira, L. P., MASSON, M. L. V.; REINALDI, M. B. D. F. M. (2014). Voz do professor: análise das leis brasileiras na perspectiva da promoção da saúde. Revista CEFAC, 16(6). 2014

[24] VIEIRA, A. B. C. et al. Fatores causais e profilaxia da disfonia na prática docente. Cadernos de Educação, Pelotas - RS. n. 28 , 2007. 